
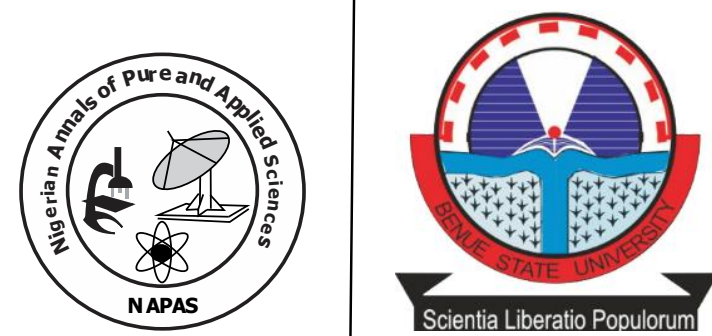

\title{
Analytical study on Fungal Cellulase Produced by Penicillium Expansum grown on Malus Domestica (Apple Fruits)
}

\author{
${ }^{*}$ Adedayo, M. R. and Ayilara, 0. V. \\ Microbiology unit, Department of Biosciences and Biotechnology, Faculty \\ of Pure and applied Sciences, Kwara State University, Malete. \\ Corresponding author: majekodunmi.adedayo@kwasu.edu.ng
}

doi: https//doi.org/10.46912/napas.235

\begin{abstract}
The rise in world industrialization and the cost of importing enzyme by local industries have led to a rise in the search for novel and native enzyme producing microorganisms. Cellulase is an enzyme that catalyzes the breaking down of carbon chains in cellulose and hemicellulose, this research therefore aimed at studying fungal cellulase produced by Penicillium expansum grown on malus domestica (apple fruits). Fresh apple fruit was allowed to deteriorate under laboratory condition until there was visible mould growth. The mould with desired features of the organism of interest was subcultured by direct plating on PDA plates to which $10 \%$ streptomycin has been added to prevent bacterial contaminants. The plates were incubated at $28 \pm 2{ }^{\circ} \mathrm{C}$ for 7 days until a visible mass of blue mycelia appear. The isolate was further subcultured onto freshly prepared media until pure culture was obtained. Characterization and identification of isolate were done using macroscopy and microscopy techniques. The isolate was re-inoculated into healthy apple fruits and the fruits were incubated at temperature of $28 \pm 2{ }^{\circ} \mathrm{C}$ for 8 days. Cellulolytic activity was examined every day throughout the incubation period. Crude enzyme was extracted each day using standard methods. Carboxyl methyl cellulose was used as standard for the crude cellulase activity assay after extraction from the infected apple fruits using Dinitrosalicylic acid (DNSA). Culture parameters like $\mathrm{pH}$ and temperature were also optimized to determine their effect on cellulolytic activity of the fungus. Cellulase activity was defined as the amount of glucose produced in $\mu \mathrm{mol} / \mathrm{mg} / \mathrm{min}$ under the assay condition. The highest cellulase activity of $86.84 \pm 0.52 \mu \mathrm{mol} / \mathrm{mg} / \mathrm{min}$ was observed on day 6 of incubation at $28 \pm 2$ ${ }^{\circ} \mathrm{C}$ and at $\mathrm{pH}$ 7. In conclusion, it is evident from this research that $P$. expansum isolated could be used as potential novel organism for industrial production of cellulase under optimized fermentation conditions.
\end{abstract}

Keywords: Malus domestica, Penicillum expansum, cellulase, enzyme activity, pure culture. 


\section{Introduction}

World major challenge has been on energy and environmental protection issues. An attempt to solve this has led to increase in demand for enzymes to catalyze several industrial processes (Jadhav et al., 2013; Saratale et al., 2014; Mostafa et al., 2019). Microbial enzymes essentially fungal enzymes have been found applicable in various commercial production processes (Pinotti et al., 2020). Due to the importance associated with enzymes of microbial origin, selected microorganisms including bacteria, moulds, yeasts and insects have been globally studied for the biosynthesis of economically viable preparations of various enzymes for commercial applications (Chirumamilla et al., 2001; Jadhav et al., 2013; Behera et al., 2017; Banerjee et al., 2020). The ability to secrete large amount of extracellular protein is characteristic of certain fungi and such strains are most suited for production of higher levels of extracellular cellulases (Ong et al., 2004). Cellulases are the group of enzymes that are capable of breaking $\beta$ 1,4 linkages in cellulose chains through hydrolysis. They are usually produced in nature by various terrestrial and marine organisms other than microbes (Szakacs et al., 2006). They are widely distributed all over the world as organisms for their production are found ubiquitously everywhere. Particularly, cellulases are produced by such organisms as plants, animals and microorganisms. Heterotrophic organisms that generally lacks the ability to utilize inorganic carbon usually possess cellulolytic ability. Many general of bacteria, Actinomycetes, yeasts and filamentous fungi produce cellulase to break down cellulose (Imram et al., 2016; Banerjee et al., 2020). Cellulolytic fungi have been reported in the genera Penicillium, Rhizopus, Fusarium Coriolus, Schizophyllum, Aspergillus, Trichoderma, Phaenerochaete and Geotrichum (Lynd et al., 2002; Li and Robinson, 2006; Imram et al., 2016; Li et al., 2016).

According to Sajith et al. (2016), the chief producers of cellulase are fungi but only few species of Penicillium were identified as good cellulase producers. Penicillium genus has been identified in the biotechnological production of a number of enzymes such as cellulase and other macromolecules possessing bioremediation potential (Leitão, 2007; Mostafa et al., 2019; Nehad et al.,2019). Certain factors such as temperature and $\mathrm{pH}$ can affect the cellulase activity of different organisms. The optimum process control parameters depend on the microbial source, desired end product, method of fermentation employed and many other such factors (Sundarram and Murthy, 2014; Banerjee et al., 2020). Fermentation has generally been an acceptable technique of biological conversion of complex organic substrates into simple molecules by various microorganisms. It has been widely used for the production of cellulase for their wide uses in industry (Bentil et al., 2018).

The major industrial applications of cellulases are in textile industry, phamaceuticals, paper making industry and household laundry detergents (Sukumaran et al., 2005). They are also used in animal feeds, in processing of fruit juice and in baking. Cellulases are also of immense importance in bioconversion of renewable organic biomass to usable biofuels and inorganic chemicals (Lynd et al., 2005; Imram et al., 2016; Sajith et al., 2016; Pinotti et al., 2020).

Agricultural wastes and other plant residues have been identified as major substrates for enzyme production by cellulolytic fungi (Milala et al., 2005). Apple (Malus domestica) is a fleshy edible fruit that is usually round, green yellow, or red produced by a small tree, it belongs to the Rosaceae or rose family. While in storage, apples are highly susceptible to decay caused by phytopathogens. Penicillium expansum has been reported as the causal agent of blue mould rot, the most devastating pathogen of harvested apples (Leitão, 2007).

Despite the wide applications of this enzyme, indigenous producing organisms are limited in supply and are mostly imported into many developing countries. Up till date few organisms have been found to be novel cellulase producers, hence the cost of importation has limited the use of the enzyme (Juturu and $\mathrm{Wu}$, 2014). Due to the search for novel organisms in the production of cellulase for local industries, this research focuses on the search for a potential organism in the Penicillium genera that can be used for production of cellulose through studying the cellulase activity of Penicillium expansum in infected apple fruits. 


\section{Materials and Methods}

\section{Sample Collection and Authentication}

Fresh healthy apple fruits were collected from Taiwo road, Ilorin, Kwara State, inside sterile sampling bags and taken to the Laboratory immediately. The apple fruit was authenticated at Herbarium Unit of the Department of Plant Biology, University of Ilorin, Ilorin, Kwara State and identified as Malus domestica "Golden delicious "e with voucher number UITH/001/1256.

\section{Preparation of Reagents}

Citrate phosphate buffer was prepared using $0.1 \mathrm{M}$ solution of citric acid and $0.2 \mathrm{M}$ solution of dibasic sodium phosphate added in the right proportions to obtain $\mathrm{pH}$ concentrations of 4 , 5,6 , and 7. $\mathrm{pH}$ of each resulting buffers was checked using a $\mathrm{pH}$ meter for accuracy. Carboxymethyl Cellulose (CMC) stock was prepared by adding one gram of CMC to each of the citrate phosphate buffers; it was allowed to fully dissolve and stored in the refrigerator at $4{ }^{\circ} \mathrm{C}$ for later use (Adejuwon et al., 2009). Dinitrosalicyclic acid (DNSA) reagent was prepare by dissolving one gram of DNSA in 100 $\mathrm{ml}$ of distilled water completely. Twenty millilitres of $2 \mathrm{M}$ sodium hydroxide and $28.2 \mathrm{~g}$ of potassium sodium tartrate and $0.6 \mathrm{~g}$ of sodium metabisulphite were added. The solution was stirred properly to homogenize completely before storing in the refrigerator at $4^{0} \mathrm{C}$ for later use (Miller, 1959; Bioencyclopedia, 2012).

\section{Isolation of fungus}

The freshly purchase apple fruit was placed inside a plastic container with lid and incubated on the lab bench to deteriorate at $28 \pm 2^{0}$ $\mathrm{C}$ until there was visible mould growth on it. The mould was subcultured by direct plating on PDA plates to which $10 \%$ streptomycin has been added to prevent bacterial contaminants. The plates were incubated at $28 \pm 2{ }^{0} \mathrm{C}$ for 7 days until a visible mass of blue mycelia appear. The isolate was further subcultured onto freshly prepared media until pure culture was obtained (Durowade et al., 2009).

\section{Identification of the Organism}

The isolated fungus was identified macroscopically and microscopically using cotton blue in Lactophenol staining technique. Data obtained were compared with literature in fungal atlas for identification. The isolated Penicillium expansum was stored in a slant and kept in the refrigerator at $4{ }^{0} \mathrm{C}$ for further use.

\section{Inoculation of Apple Fruits}

Healthy apple fruits were surface sterilized using $70 \%$ ethanol and then rinsed with several changes of sterile distilled water to remove residual ethanol. A sterile $7 \mathrm{~mm}$ cork borer was used to remove tissue disc from the apple fruits. They were inoculated with 7 days old culture of the Penicillium expansum isolated and then the discs were replaced. A control experiment was also set up without fungal inoculation. Both the experimental and control fruits were placed in separate sterile glass containers labeled 1-8, and incubated at $28 \pm 2{ }^{\circ} \mathrm{C}$ for 8 days. Observation for deterioration was made daily after every 24 hours (Adejuwon et al., 2009).

\section{Extraction of Crude Enzymes}

The infected part of the apple was cut and smashed inside sterile beaker using the sterilized flat part of a spatula. One gram of it was weighed and homogenized in $100 \mathrm{ml}$ of sterile distilled water. The homogenate was placed on a shaker at $200 \mathrm{rpm}$ for 1 hour and then filtered through four layers of muslin cloth. It was further clarified by filtering through Whatman Number 1 filter paper and the $\mathrm{pH}$ was checked using a $\mathrm{pH}$ meter and recorded. The extract, taken as the crude enzyme was analyzed for cellulase activity using the method of Miller (1959) as described by Adejuwon et al. (2009).

\section{Enzyme Assay}

DNSA assay which is known as dinitrosalicyclic acid assay method was used to determine the amount of reducing sugar left after reacting the crude enzyme with CMC stock in phosphate citrate buffer. Two $\mathrm{ml}$ of the buffer (CMC) was added to $2 \mathrm{ml}$ of the crude enzyme in a test tube and the mixture was incubated at $37{ }^{\circ} \mathrm{C}$ for 1 hour. A control experiment was also set up without adding the crude enzyme (Adejuwon et al., (2009). Precisely $2 \mathrm{ml}$ of dinitrosalicylic acid reagent was added to $2 \mathrm{ml}$ of the enzyme substrate mixture and the control tube to terminate the reaction. The tubes were kept in boiling water bath for 10 minutes and allowed to cool under running water. Reducing sugar released was measured by 
reading the absorbance of the mixture at $540 \mathrm{~nm}$ using UV-spectrophotometer.

Enzyme activity: one unit of cellulase activity was defined as the amount of enzyme that produced one unit of glucose in $\mu$ mol per mg per minute $(\mu \mathrm{mol} / \mathrm{mg} / \mathrm{min})$ under the assay condition (Sudeep et al., 2020).

Optimization of culture parameters for cellulase activity

Inoculated apple fruits were incubated under different temperatures of 30 and $40{ }^{\circ} \mathrm{C}$, all other conditions were kept constant. CMC stock in phosphate citrate buffer with varying $\mathrm{pH}(\mathrm{pH} 4$, 5,6 , and 7) were used to determine the optimum $\mathrm{pH}$ for the enzyme activity (Gao et al., 2008).

\section{Results}

Isolation and Identification of Organism used as Inoculum

The organism isolated from the deteriorating apple fruit was identified as Penicillium expansum. Macroscopic characteristics of the isolate are bluish-green colour (direct), heavy sporulation, musty earthy odour, and slow growth rate. Microscopic characteristics of the isolate are conidia head, conidiospores and presence of septate hyphae (Plate 1 and Table 1).

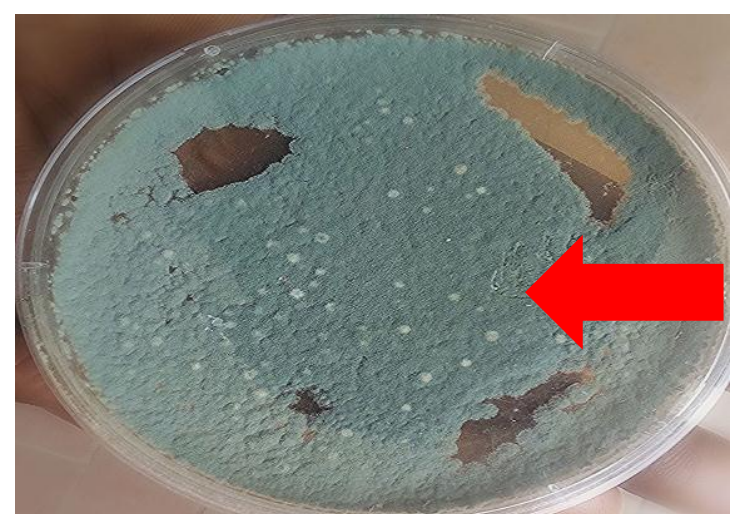

Plate 1: Penicillium expansum (Blue-green mycelia) on plate

Table 1: Macroscopic and Microscopic Characteristics of the Fungal Isolate

Techniques

Macroscopic
Characteristics

Colour (direct)

Colour (reverse)

Texture

Sporulation

Spore colour

Young mycelia colour

Odour

Growth pattern

\section{Cellulase Activity}

The highest cellulase activity of $86.84 \pm 0.52 \mu \mathrm{mol} / \mathrm{mg} / \mathrm{min}$ was obtained after day 6 of incubation while the lowest of $2.00 \pm 0.34$ $\mu \mathrm{mol} / \mathrm{mg} / \mathrm{min}$ was obtained after day 1 . The enzyme activity increased from days 1-6 after which it began to decrease until day 8 (Figure 1).

\section{Effects of Temperature on the Cellulase Activity}

The highest cellulase activity of $86.84 \pm 0.52 \mu \mathrm{mol} / \mathrm{mg} / \mathrm{min}$ was obtained at $30^{\circ} \mathrm{C}$ at day 6 of incubation and the least cellulase activity of $2.00 \pm 0.34 \mu \mathrm{mol} / \mathrm{mg} / \mathrm{min}$ was obtained at $30{ }^{\circ} \mathrm{C}$ at day 1 of incubation (Figure 2). At $40{ }^{0} \mathrm{C}$, the highest enzyme activity was $73.48 \pm 0.21$ $\mu \mathrm{mol} / \mathrm{mg} / \mathrm{min}$ at day 5 and the lowest activity was $4.15 \pm 0.40 \mu \mathrm{mol} / \mathrm{mg} / \mathrm{min}$ at day 1 of incubation (Figure 2).

\section{Effects of Buffer pH on Cellulase Activity}

The highest enzyme activity of $86.84 \pm 0.52$ $\mu \mathrm{mol} / \mathrm{mg} / \mathrm{min}$ was obtained at $\mathrm{pH} 7$ and at day 6 while the lowest activity of $2.00 \pm 0.34$ $\mu / \mathrm{mg} / \mathrm{mol} / \mathrm{min}$ was obtained at day 1 (Figure 3 ). $\mathrm{pH}$ of Crude Enzyme

The $\mathrm{pH}$ reading ranges between 4.53 to 7.73 during the period of incubation (Figure 4). 
of colourless drops when the culture was old.

Slow

Microscopic

Growth rate

Type of spore bearing structure

Conidia

Type of spores

Type of hyphae

Conidiospores

Probable organism

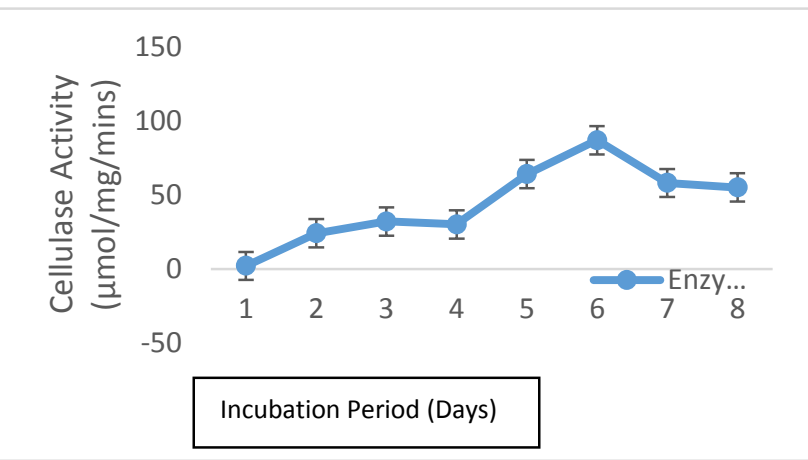

Figure 1: Cellulase Activity of Penicillium expansum in rotten apple fruits).

Data are means \pm SD

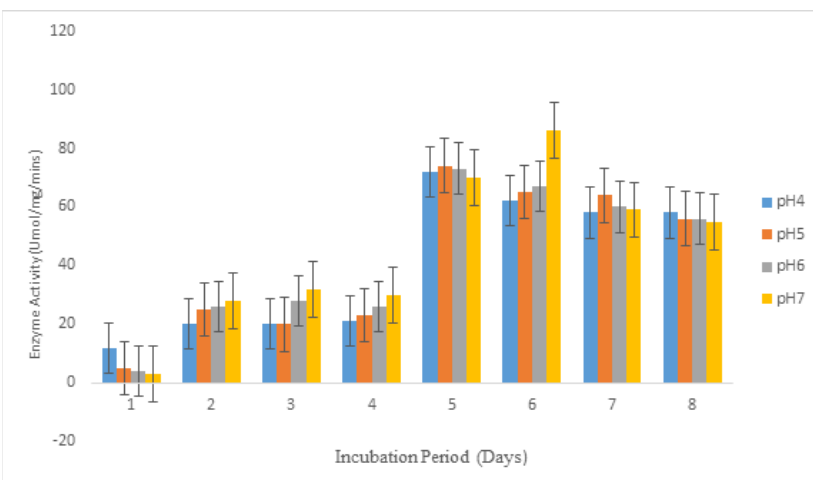

Figure 3: Effects of $\mathrm{pH}$ on cellulase activity

Data are means $\pm \mathrm{SD}$

\section{Discussion}

Cellulase activity in apple fruits infected by Penicillium expansum was studied. The isolated fungus in this study, Penicillium expansum exhibited cellulolytic ability. Penicillium species among other fungi have been known and described by previous authors as possessing ability to secrete many types of extra cellular enzymes including cellulase (Adeleke et al., 2012; Mostafa et al., 2019; Sudeep et al., 2020). Cellulase production by $P$. expansum was affected by varying temperature, $\mathrm{pH}$ and inoculation period. The highest cellulase activity observed on day 6 may be due to decrease in nutrient or accumulation of waste after day 6 which led to decrease in the rate of multiplication of the organism, thus, leading to decrease in the

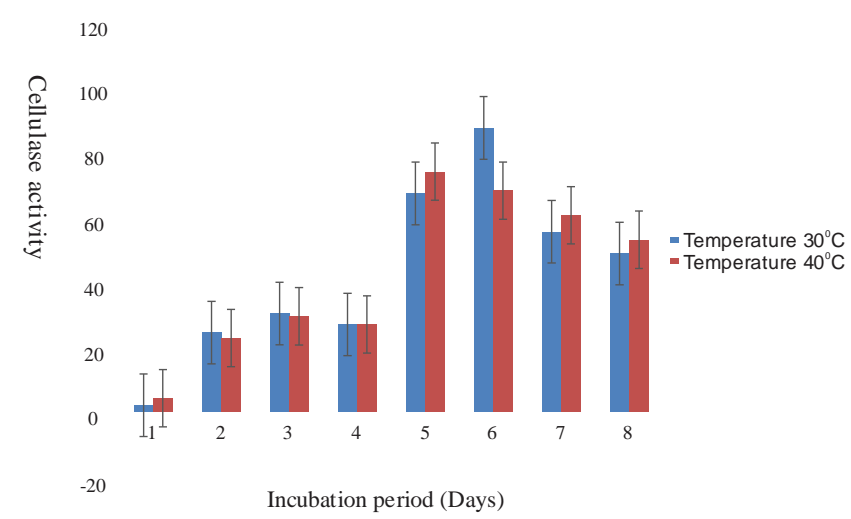

Figure 2: Effects of Temperature on Cellulase Activity Data are means \pm SD

enzyme activity. The lowest cellulase activity obtained on day 1 may be traceable to the organism just entering the lag phase hence the multiplication rate was slow, resulting in low enzyme production. This finding was contrary to the report of Bamigboye (2013), who recorded highest cellulase activity by fungi associated with maize cob degradation on day 3 . This disparity might be due to difference in substrate used, the fermenting fungus and also difference in length of the incubation periods.

The organism was able to grow over the range of temperature from $28 \pm 2{ }^{0} \mathrm{C}$ to $40{ }^{0} \mathrm{C}$. However, maximum cellulase activity was obtained at $28 \pm 2{ }^{\circ} \mathrm{C}$. This temperature coincides with the optimum range of growth for fungi generally, hence it allows for better growth of the isolate. However, sometime optimum temperature does not coincide with optimum enzyme activity. The result was similar to what was reported by Bamigboye (2013) who indicated that the optimum temperature for cellulase production was $30{ }^{\circ} \mathrm{C}$ Also, Penicillium expansum was found to grow most efficiently within all the temperature range tested.

The $\mathrm{pH}$ of the medium is one of the most important parameters that influenced enzyme activity. The optimum $\mathrm{pH}$ for cellulase activity using $P$. expansum was obtained at 7 . This was contrary to the result of Prasanna et al. (2016); 
Mostafa et al. (2019) who reported an optimum $\mathrm{pH}$ of 5 for cellulase production by a Penicillium sp but similar to the observation of Banerjee et al. (2020). This disparity might be due to the fact that fungi has been found to grow over a wide $\mathrm{pH}$ range of 2 to 9 (Coral et al., 2002), although optimum $\mathrm{pH}$ for growth may not correspond to optimum $\mathrm{pH}$ for cellulase activity. Increase in $\mathrm{pH}$ of the crude enzyme indicates a decrease in the acidity level of the enzyme while decrease in $\mathrm{pH}$ of the crude enzyme indicates an increase in the acidity level of the enzyme.

\section{Conclusion}

From the results obtained from this study, $P$. expansum could be a novel organism to produce cellulase for local industrial use under optimized culture conditions. The factors which supported high production of cellulase from the substrate were incubation period of 6 days, temperature of $28 \pm 2{ }^{\circ} \mathrm{C}$ and $\mathrm{pH} 7$

\section{References}

Adeleke, A. J., Odunfa, S. A., Olanbiwonninu, A. Owoseni, M. C. (2012). Production of Cellulase and Pectinase from Orange Peels by Fungi. Nature and Science 10(5):107112]. (ISSN: 1545-0740). http://www. sciencepub.net/nature.

Adejuwon, A. O., Oni, A. O., Ajayi, A. A., Olutiola, P. O. (2009). Cellulase Activity in Tomato Fruits Infected with Penicillium funicolusum Thom. African Journal of Plant Science. 3: 113-116.

Banerjee, S., Maiti, T. K. and Roy, R. N. (2020). Production, purification, and characterization of cellulase from Acinetobacter junii GAC 16.2, a novel cellulolytic gut isolate of Gryllotalpa africana, and its effects on cotton fiber and sawdust. Annals of Microbiology (2020) 70:28 https://doi.org/10.1186/s13213-020 01569-6

Bamigboye, O. O. (2013). Screening of some Fungi associated with Maize cob degradation for cellulase activity. Greener Journal of Agricultural Science. 3(6): 492-496

Behera, B.C., Sethi, B.K., Mishra, R.R., Dutta, S.K, Thatoi, H.N. (2017). Microbial cellulasesDiversity \& biotechnology with reference to mangrove environment: A review. Journal of Genetic Engineering Biotechnology 15:197-210.
Bentil, J.A., Thygesen, A., Mensah, M., Lange, L. and Meyer, A.S. (2018). Cellulase production by white-rot basidiomycetous fungi: solid-state versus submerged cultivation. Applied Microbiology and Biotechnology 102:5827-5839

Bioencyclopedia, (2012). Estimation of Reducing Sugars by the Dinitrosalicylic Acid Assay Method.

www.eplantscience.com/index/biotechnolo gy_methods/biochemistry/estimation_

Chirumamilla, R. R., Muralidhar, R., Marchant, R., Nigam, P. (2001). Improving the

Quality of Industrially Improved Enzymes by Directed Evolution. Mol. Cell Biochem. 2: 159-168.

Coral, G. K., Arikan, B., Unaldi, M. N. and Guvenmez, H. (2002). Some Properties of Crude Carboxylmethyl cellulase of Aspergillus niger Z10 wild-type train. Turk. J. Biol. 26: 209-213.

Durowade, K. A., Kolawole, O. M., Udin II, R. O., Enonbun, K. I. (2009). Isolation of Ascomycetous Fungi from a Tertiary Institution Campus Soil. Journal of Applied Sciences and Environmental Management. 12: 57-61.

Gao, J., Weng, H., Zhu, D., Yuan, M., Guan, F., Xi, Y. (2008). Production and Characterization of Cellulolytic Enzymes from the Thermoacidophilic Fungus Aspergillus terreus M11 under Solid-state Cultivation of Corn Stover. Bioresour Technol. 99:76237629

Imran, M., Anwar, Z., Irshad, M., Asad, M.J. and Ashfaq, H. (2016). Cellulase Production from Species of Fungi and Bacteria from Agricultural Wastes and Its Utilization in Industry: A Review. Advances in Enzyme Research, 4, 44-55. http://dx.doi.org/10. 4236/aer.2016.42005

Jadhav A.R., Girde A.V., More S.M., More S.B. and Saiqua K. (2013). Cellulase Production by Utilizing Agricultural Wastes. Research Journal of Agriculture and Forestry Sciences ISSN 2320-6063. Vol. 1(7), 6-9.

Juturu, V. and Wu, J.C. (2014). Microbial cellulases: engineering, production and applications. Renewable and Sustainable Energy Reviews 33:188-203.

Leitão, A. L. (2007). Biodegradation of Phenol and Resorcinol by a Halotolerant Penicillium. In: Wand, B. Y. editor. Environmental 
Biodegradation Research. Nova Science Publishers Inc; New York, USA. 273-287.

Li, Y., Liu, C., Bai, F. and Zhao, X. (2016). Overproduction of cellulase by Trichoderma reesei RUT C30 through batch-feeding of synthesized low-cost sugar mixture. Bioresour. Technol., 216: 503-510.

Li, M. H., Robinson, E. H. (2006). Use of Cottonseed in Aquatic Animal Diets: a review. North Am. J. Aquaculture 68: 14-22.

Lynd, L. R., Weimer, P. J., van Zyl, W. H. and Pretorious, I. S., (2002) Microbial cellulase utilization: Fundamentals and biotechnology, Microbiol Mol Biol 66: 506577.

Lynd, L.R., Van Zyl, W. H., McBride, J. E. and Laser, M. (2005) Consolidated bioprocessing of cellulosic biomass: an update. Curr Opin Biotechnol 16:577-583

Milala, M.A., Shugaba, A., Gidado, A., Ene, A.C. and Wafar, J.A. (2005). Studies on the use of Agricultural wastes for cellulase enzyme production by Aspergillus niger. Research Journal of Agriculture and biological Sciences. 4: 323-325.

Miller, G.L. (1959). Use of Dinitrosalicylic acid reagent for determination of reducing sugar. Anal. Chem., 426-428.

Mostafa, S.A., Khattab, H. H., Azzaz, Ahmed M. Abd-El T. and Hussein A. M. (2019). Production Optimization of Fungal Cellulase and its Impact on Ruminal Degradability and Fermentation of Diet. International Journal of Dairy Science, 14: 61-68.

Nehad, E.A., Yoness, M.F. and Reem, A.A. (2019). Optimization and purification of cellulase produced by Penicillium decumbens and its application. Egypt Pharmaceut J. 2019;18: 391-402.DOI: 10.4103/epj.epj_3119,18(4)

Ong, L. G., Abd-Aziz, S., Noraini, S. (2004). Enzyme Production and Profile by Aspergillus niger During Solid Substrate Fermentation Using Palm Kernel Cake as Substrate. Appl. Biochem Biotechnol. 118: 73-79.

Pinotti, L. M., Paulino, L. B., Agnezi, J. C., dosSantos, P. A., Da-Silva, H. N. L., Zavarise,
J. P., Salomão, G. S. B. and Tardioli, P. W. (2020). Evaluation of different fungi and bacteria strains for production of cellulases by submerged fermentation using sugarcane bagasse as Carbon source: Effect of substrate concentration and cultivation temperature. African Journal of Biotechnology, 19(9); 625-635. DOI: 10.5897/AJB2020.17210

Prasanna, H. N., Ramanjaneyulu, G. and Reddy, B. R. (2016). Optimization of cellulase production by Penicillium sp. Biotchnol. 6: 162.

Sajith, S., Priji, P., Sreedevi, S. and Benjamin, S. (2016). An Overview on Fungal Cellulases with an Industrial Perspective. J. Nutr. Food Sci. 6: 461. doi:10.4172/21559600.1000461

Saratale, G. D., Kshirsagar, S. D., Sampange, V. T., Saratale, R. G., Oh, S. E., Govindwar, S. P. and Oh, M. K. (2014). Cellulolytic Enzymes Production by Utilizing Agricultural Wastes Under Solid State Fermentation and its Application for Biohydrogen Production. Appl Biochem Biotechnol. 174: 2801-2817 DOI 10.1007/s12010-014-1227-1

Sudeep, K.C., Upadhyaya, J, Joshi, D. J., Lekhak, B., Chaudhary, D. K., Pant, B. R. Bajgai, T. R. Dhital, R., Khanal, S., Koirala, N. and Vijaya Raghavan, V. (2020). Production, Characerization, and Industrial Application of Pectinase Enzyme Isolated from Fungal Strains. MDPI; Fermentation; 6:59

Sukumaran et al., (2005). Microbial Cellulases Production, Applications and Challenges. Journal of Scientific \& Industrial Research. 64: 832-84

Sundarram, A. and Murthy, K. P. (2014). $\alpha$-amylase Production and Applications: A Review. Journal of Applied and Environmental Microbiology. 2: 166-175.

Szakacs, G., Tengerdy, R. T. and Nagy, V. (2006). Cellulase. In: Enyme Technology ed., (Pandey, A., Collin, W., Soccol, C. R. and Lorroche, C., eds) Spring Science + Business Media, Inc. and Asia tech. 235247. 